\title{
Sacred Lineages of Samarqand: History and Identity
}

\author{
Azim Malikov
}

\begin{abstract}
The Kazakhs, Turkmens, Tajiks, Qaraqalpaqs, Uyghurs and Uzbeks in Central Asia share some distinct sacred lineages - Sayyids and Xojas - some of which appear in two or more of these ethnic groups. In the article, I will analyse some data on the history and identity of Islamic sacred lineages of Samarqand, compiled during ethnographic research of the population and archival materials. I will analyse the stories of the representatives of sacred families about their past, as well as published narratives. The analysis of the sources shows that despite the preservation of the historical family library, a secularised society and the Sovietera education influenced the views and the identity of sacred families.
\end{abstract}

Keywords: belonging, Central Asia, elite, Ishan, Islam, kinship, Uzbekistan

Most studies on the identity of Uzbekistan's population are devoted to the study of national and ethnic identities. I argue that the study of lower-level social units (clans and lineages) is also important for understanding the identity formation processes. Frequently, the same clan can be found in more than one ethnic group (Schlee 1994).

To understand the complex of identities that includes ethnic as well as regional, religious and others, the concept of multiple identities (multiidentity) has a valuable significance (Burke 2003: 195). Multi-identity manifests itself in the fact that an individual can belong to several groups that exist at different levels and with which he can identify himself in different social situations. Among the population of Central Asia, ethnolinguistic, tribal, regional, religious and socioreligious identities are distinguished (Roy 2000: 18). A question arises regarding the many types of identity available to individuals: which type of identity is the most sustainable one? Although everything 
is related to the social and cultural context, nevertheless, an important condition is the factor of status.

The study of the history of Muslim sacred lineages, such as the Sayyids, ${ }^{1}$ $\mathrm{Xoja}^{2}$ and Ishans ${ }^{3}$ of Central Asia, is of considerable historical interest. Researchers point out that the study of the kinsfolk of the Prophet Muhammad in different Muslim societies is still a relatively unexplored area of research (Morimoto 2004: 87-103). In the past, Islamic sacred lineages were one of the many descent elite groups in Central Asia and ranked high in the social hierarchy. Sacred families used various self-names that depended on the regional and cultural contexts. Researchers call them by the generic terms 'descendants of saints' or 'white bone' (oq suyak in Turkic) (Abashin 2001: 65). 'Sacred lineages' are defined variously based on differing criteria.

Nowadays, the Kazakhs, Qaraqalpaqs, Tajiks, Turkmens, Uyghurs and Uzbeks in Central Asia share distinct groups, some sacred lineages of which appear in two or more of these ethnic groups. A lineage is usually a group of people who trace descent unilineally from a common ancestor through a series of links that can be enumerated (Holy 1996: 74-75). Symbolic resources of the identity of sacred lineages are represented by shrines, genealogies, legends about miracles, etc.

The famous orientalist Vasiliy Bartold (1869-1930), analysing the history and genealogies of Xojas, claimed that the genealogical records of Xojas had traces of forgery (Bartold 1963: 276). This idea was developed in the publications of some Soviet and post-Soviet researchers (Abashin 2003: 234). During the Soviet period, researchers sought to study sacred lineages using ethnic criteria, but had to recognise their special status (Sukhareva 1960).

Over the past two decades, researchers have published much about macroethnic identities: Tajik, Uzbek, Uzbekistani, etc. (Adams 2010; Khalid 2015). However, there is quite little anthropological research concerning the identities of small social groups of such sacred lineages. This issue was first raised by John Schoeberlein-Engel (1994), followed by the publications of Bruce Privratsky (2004), Sergey Abashin (2001), Zilikha Ibadullaeva (2001), etc. A significant part of these studies dealt with the local societies. Among Bruce Privratsky's main informants were the descendants of famous Sufi leader and theologian Makhdumi A'zam (Sayyid Jalal ad-din Ahmad al-Kasani) (14611542) in Turkistan (southern Kazakhstan). However, their external connections, communications with Samarqand sacred families, remained beyond his research. A large number of publications on the history of Xojas, the descendants of Makhdumi A'zam, have been published by researchers, especially their activities in eastern Turkistan (Papas 2018).

I studied the sacred lineages in the Samarqand province of the Republic of Uzbekistan, which until now have not been specifically studied. Samarqand had great significance in symbolising the local population of Islamic sacredness. Samarqand was one of the biggest religious centres in Central Asia, with a concentration of a large number of Xojas and Sayyids of various lineages. 
Sacred lineages of the Samarqand province linguistically consist of two groups: Uzbek-speaking and Tajik-speaking. Some sacred families are bilingual and speak both Tajik and Uzbek.

Samarqand's best-known sacred families are the descendants of Sufi leaders such as Xoja Ahrar (1404-1490) and Makhdumi A'zam (1461-1542), the descendants of Sayyid Ata (first half of 14th century) and Mirakoni Xojas (Sayyids from Mirakon village in Iran). I give special attention to the local classification of the sacred families of Samarqand, the use of history to construct the history of sacred families in the modern period. This article focuses on how Sayyids and Xojas express their identity as the descendants of sacred families through publications and stories about their past and their ancestors.

In this article, I will analyse data on the history and identity of Islamic sacred lineages of Samarqand. Attention is paid to such issues as: the perception of their group and their past by sacred families, and the perception of sacred lineages by other population groups of the Samarqand region. The material is based on the study of the families of the descendants of Islamic and Sufi intellectuals from the lineage of a major Sufi figure of the sixteenth century, Ahmad Kasani or Makhdumi A'zam ('the greatest master').

The data presented in this article was collected during multiple short-term field research trips between 2004 and 2009, mainly to Samarqand province in Uzbekistan. In 2018-2019 semistructured interviews were held with the Xojas of Samarqand city and province. At the same time, the method of included participant observation was practiced.

One of my key informants was Komilhon Kattaev, a local historian of Samarqand, a descendant of Makhdumi A'zam. He worked as a researcher in the Samarqand Department of the Academy of Sciences of the Republic of Uzbekistan and the State Museum of the History of Culture of Uzbekistan. He is the founder and head of the Makhdumi A'zam Dahbidi Foundation. He has published dozens of books and hundreds of articles on the history of Samarqand, shrines, Sufi saints and outstanding figures of the city. A unique catalogue of manuscripts of his hereditary library, consisting of thirteenth- to nineteenth-century manuscripts, was published in 2015. Some of them were personally owned by Makhdumi A'zam (Kattaev 2015).

I argue that the Soviet policy of modernising and homogenising the society in Central Asia and creating national identities did not eliminate some specific descent identities in the region. Despite the Soviet nationality policy, the struggle against religion, the repressions against sacred lineages, the creation of new national stories and secular politics, some families belonging to sacred lineages preserved their identity. My data shows that language is not an important criterion in drawing boundaries between various sacred lineages. 


\section{Theoretical Approach}

According to Fredrik Barth's (1994) concept, many types of identities are available to people that can be applicable in different situations. During the period under review, we choose one or a limited number of identities as guidelines. In some situations, we want to note a distinction, and in others we are looking for something general or a general affiliation. Richard Jenkins argues that individual and collective identities can be understood using a model of dialectical interaction of internal and external definition processes (2008: 46). Identity at one level or another is expressed through either discourse or through everyday social behaviour (Giddens 1991: 70).

Individuals are unique, but in the processes of primary and subsequent socialisation and in their constant interactions, individuals define and redefine themselves and others throughout their lives (Jenkins 2008: 40). Society can offer a person only a choice of different behaviours, but it cannot determine the selections that are taken depending on the situation. In life, there is always a private personal space in which there is a choice to express yourself. It is possible to choose and relate to certain norms of society (Layder 2004: 9). Therefore, understanding group identity helps the study of individual identity and its interaction with collective identity. While studying the multiple identities of sacred lineages, levels such as social, religious, regional, national, ethnic can be distinguished. Thus, a complex pattern of variable identities is formed.

The study of the history of powerful sacred lineages in the past helps to understand different ways in which the local Muslim religious elite adapted to changes in the political, religious-ideological, social and economic systems in Uzbekistan. According to Michael Woods, the elites are socially and discursively constructed as elites either by themselves or by others and have privileged access to or control over certain material and symbolic (knowledge) resources (1998: 2105, 2108).

\section{Historical Review}

In the pre-Soviet period (before 1917), Central Asia did not have any ethnicnational differences among its population. People distinguished each other by social characteristics: religious, village versus city, nomadic versus settled, as well as by local cultural categories, such as wealth, social status, region, language or dialect (Abramson 2001: 179-180).

The Sayyids or Alids emerged as one of the local elites in Central Asia by the late ninth century (Bernheimer 2005: 44). Sayyids have enjoyed a privileged position in almost all Islamic countries. In the pre-Soviet period, the criteria used to recognise different groups of sacred lineages were the genealogy (nasab-noma) and the name of an ancestor who was a Sufi figure. The ancestors of Samarqand sacred families (Ahrari - the descendants of Xoja 
Ahrar, Makhdumi Azzam and Sayyid Ata) participated in the coronations of the rulers of the Bukharan Emirate ${ }^{4}$ (Akhmedov 1985: 118-119). During the time of the Bukharan Emirate, the richest and the most eminent families of the 'sacred lineages' had waqfs ${ }^{5}$ that were exempt from state taxes. The families of the descendants of Xoja Ahrar, Sayyid Ata and Makhdumi A'zam contracted marriages with the representatives of the reigning Manghyt dynasty. Some 'sacred lineages' had certain monopolies in the field of Islamic jurisprudence, or knowledge of Islam.

In the pre-Russian period (before 1868), the representatives of 'sacred lineages', who had written genealogies, lived in different regions of Central Asia. Makhdumi A'zam's descendants had a known political and social influence not only in the Bukharan khanate but also in the Kokand khanate and western China in the nineteenth century (Yaoyi 2010: 123, 137). During this period Xojas were venerated as Sufi saints (Ishan) (Papas 2018).

The state policy aimed at undermining the status of sacred lineages began after Samarqand joined the Russian Empire (Malikov 2019). A serious transformation of the economic and social status of sacred families occurred during the Soviet period under the influence of the state. The state played a crucial role in the national identity formation process in Central Asia in the Soviet period. Barth says that the state is 'a specifiable third player in the processes of boundary construction between groups' (1994: 19). During the Soviet period, state resources were mobilised to create strong secular ethnonational identities (Khalid 2014: 2) and the birth of local nationalisms. The undermining of the religious perception of the world in Muslim societies of Central Asia was facilitated by a twofold change: the alphabet, and persecution and destruction of those who played an important role in preserving and transmitting any intellectual tradition that might exist (Louw 2007: 52).

After the national-territorial separation of 1924, the descendants of Makhdumi A'zam found themselves officially registered as a part of different titular nations: the Tajiks, Kazakhs, Uzbeks and Uyghurs. Based on their own principles of ethnic engineering, anti-religious and class struggle in the USSR, the Soviet authorities, first, deprived the sacred lineages of legal status and, second, refused them the right to be registered as a separate community. The Soviet authorities carried out brutal repressions against the representatives of sacred lineages in the 1930s, especially against many Ishans and their children (Shamsuddinov and Kholmirzaev 2015: 74-236).

Over the past one hundred years, as a result of several factors - the policy of ethnic engineering during the period of Soviet rule, the emergence of nationstates, the modernisation and transformation of Muslim society in Central Asia - important changes in the identity of the population have taken place. The Soviet government sought to form relatively homogeneous ethnic societies for 70 years. This policy continued in the independent states of Central Asia. Nevertheless, the identities of individual social groups typical for the pre-Soviet period persist even today. 
During the Soviet period, individual families preserved a certain level of knowledge of Islam and Islamic traditions. Other representatives of sacred lineages, having mastered new knowledge based on the Soviet ideology, achieved high political and administrative positions during the Soviet period. However, these achievements were in no small part related to their personal ties with the communist leadership of the USSR.

In the twentieth century, there was a social and ethnic transformation of sacred lineages, which caused a change in their identity. Some Xoja families sacrificed their religious identity in order to announce themselves 'bearers of national consciousness' and 'the intellectual elite' (Abashin 2005: 78). According to my observations, at present, despite the Soviet policy of ethnic engineering, the descendants of the most powerful sacred lineages in Samarqand preserved their specific identity.

After the independence of Uzbekistan, despite a revival of Islam, the public space remains de-Islamised and secular (Khalid 2014: 121). Against the background of the secular politics of the Soviet era and the modern period, at present, a large part of the population has an extremely limited understanding of Islam, the history of Sufism and the role of Islam in the history of the region. It should be noted that the name of Makhdumi A'zam as an outstanding theologian is mentioned in the official history of Uzbekistan and school textbooks on history.

Samarqand is one of the largest cities in Uzbekistan. Representatives of different nationalities (mainly Tajiks, Uzbeks, Irani, Russians, Tatars, Arabs, etc.) live in Samarqand. As Laura Adams notes, it is often difficult to distinguish Tajiks from Uzbeks by physical type, names or any common markers of ethnicity (2013: 118). However, if one studies the social structure of the society more deeply, one can identify the descendants of the sacred lineages.

\section{Sacred Lineages in the Perceptions of the Local Population in the Post-Soviet Period}

Individual and collective identities are equally an interactive product of 'external' identification by others as well as 'internal' self-identification (Jenkins 2008: 200-201). It should be noted that at present the definitions of sacred families differ according to the region of Central Asia. Researchers argue that the descendants of Makhdumi A'zam in eastern Turkistan are referred to as 'Xojas of Kashgar' and as 'Makhdūmzāda' (Papas 2018). In Bukhara and Samarqand, Xojas can be either the descendants of the Prophet, the first caliphs or leaders of the Sufi brotherhoods. ${ }^{6}$ In the past, there were communications between specific groups of sacred lineages living in different regions, driven by several mutually overlapping reasons: family ties, leadership or membership in Sufi brotherhoods, visiting shrines or graves of ancestors, etc. 
In the Samarqand region, the population uses the common word eshon (Ishan) to refer to the descendants of sacred lineages (Sayyids, Xojas). In the pre-Soviet period, the term referred to the leaders of the Sufi brotherhood and their descendants. Currently, in the context of secular Islam in Uzbekistan, there are no Sufi brotherhoods in the Samarqand region, but the population traditionally continues to use the term Ishan. According to an informant, Ishan in the Persian language means 'they'. This word was used in relation to the Sufi leader, the pir, because it was forbidden to call him by name. Not only the descendants of the Prophet Muhammad, but also people from ordinary classes (qara) could be Ishan. 'Xoja' means 'the representative of the highest class' (oliy tabaqa) (interview, native of Samarqand, 2005).

An important criterion for the identification of sacred lineages is the belief of a certain part of the local population in their origin from the Prophet Muhammad, revered caliphs and Sufi saints, which reinforces the perception of the religious component in their lifestyle and identity. In representations of the 'non-elite' population, the descendants of 'holy groups' still have their own lifestyle features. This particularly contrasts with the inhabitants of some rural areas, where the descendants of saints are credited with higher moral qualities, a culture of behaviour and a dialect. Their religiosity, the association with the family of the Prophet Muhammad and the supernatural qualities that were attributed to them helped them maintain a high status among the population, especially among the descendants of seminomadic groups.

Xojas of various lineages live in Samarqand. Among them are the Xojas of Sayyid Ata, the descendants of Makhdumi A'zam, Mirakon Xojas living mainly in the Qozikalon block, the descendants of Xoja Ahror Vali, the descendants of the caliph Usman and other small groups.

The village of Dahbid, located 14 kilometers to the north of Samarqand, is the homeland of Makhdumi A'zam's descendants. In the perception of the locals of Dahbid, the descendants of Makhdumi A'zam who moved from Dahbid to the Samarqand region call themselves Xoja. According to my interlocutor: 'The Xojas follow endogamous marriages and do not mix with the qara [commoners]. Xoja contract marriages with Xojas from other regions. There is a difference in the dialect of Xoja and commoners. Qara speak more a Kipchak dialect of Uzbek, and Xojas speak the Uzbek literary dialect' (interview, native of Dahbid, 2004). Thus, literary Uzbek, and in some cases also the Tajik language, serve as markers of external identity by which the surrounding people highlight sacred lineages. Jenkins said that the personal name is one of the defining signs of an individual distinction. Although a personal name means individuality, it also positions its owner in terms of collective similarities (and, of course, differences) (2008: 21). Sacred lineages of Samarqand and other regions of Central Asia have special attachments to the names (Khon, Sayyid, Eshon) that distinguish them from other groups. The term Ishan is used across wide swaths of the modern territories of Afghanistan, Iran, Kazakhstan, Tajikistan and Turkmenistan. There are Ishans and Sayyids 
among the Turkmens of Iran, and there are cases when an Ishan holds the post of the head of a village. They have a genealogy that is framed and very complicated. Generally, the local population has a great respect for their religious dignitaries (interview, Professor Soheila Shakhshakhani, 2018).

\section{The Construction of the History of Makhdumi A'zam Descendants}

Identity is created and reproduced both in the discourse - narrative, rhetoric and representation - as well as in the practical implications of identification (Jenkins 2008: 200-201). The construction of the past is an act of self-identification, as it creates a link between what is supposed to have happened in the past and the current situation. At the same time, the construction of the past is socially motivated in certain historical and social circumstances (Friedman 1992: 837, 856). Knowledge of family history can play a big role in the construction of identity in the present (Bennett 2015: 9).

Despite the 74 years of Soviet power, the struggle against religion, the repressions against sacred lineages, the creation of new national stories and secular politics, individual sacred lineages still preserve their specific identity, certain traditions and an interest towards their past and genealogies.

The names of the descendants of Makhdumi A'zam are also associated with the construction of the architectural masterpiece of Samarqand, the Sherdor madrasa, which is promoted by the state as part of the cultural heritage of Uzbekistan. Thus, the history of the descendants of the saint successfully fits into the modern nation-building process in Uzbekistan.

After the collapse of the Soviet Union, Kattaev, one of my informants, published a book that reflects his views on his family's past. Many of his sources are hagiographies and unpublished manuscripts from his private library. This small book in Uzbek is notable because a publication of this kind was published for the first time after 74 years of Soviet rule. The book is dedicated to the memory of the author's ancestors (Kattaev 1994). Kattaev's book on Dahbidi Xojas is a wonderful source on the history of the descendants of Makhdumi A'zam. It provides insight into the level of knowledge of Islam and the Sufism of his Samarqand descendants towards the end of the Soviet era.

In his book, Kattaev seeks to draw connections between the past and the present, the local and the global, through the history of Makhdumi A'zam's family and descendants. He emphasises that Makhdumi A'zam and his dahbediy hojalar (Xojas of Dahbid) descendants influenced the religious, cultural, spiritual and sociopolitical life of the population of a large territory, including Central Asia, eastern Turkistan, Afghanistan, India, Pakistan and Iran's Khorasan (Kattaev 1994: 3). He does not give any information about Xojas as a separate social and privileged group in the past. The book noticeably attempts to connect local identity (Dahbid) as a Sufi center in the past and the influence of his Xojas from eastern Turkistan to India. 
The author describes the activities of Makhdumi's son, A'zam Xoja Ishoq Vali, whose descendants founded the state of Xojas (khozhalar davlati) in eastern Turkistan (Kattaev 1994: 33). The author cites the version of the story that Xoja Ishoq's mother was Bibichai Kashqarii of the Qarakhanid ${ }^{7}$ dynasty, so he was on a par with Afaq Xoja, a descendant of another son of Makhdumi A'zam who was entitled to rule in eastern Turkistan. According to Kattaev, the descendants of Xoja Kalonhoja were involved in religious administration, and the descendants of Xoja Ishaq Vali were destined to engage in secular rule (Kattaev 1994: 33, 40).

A separate paragraph of the book is devoted to the coverage of Khidoyatullo Afaqkhoja's activities in eastern Turkistan. The author does not allow the politicisation of this topic or any negative attitude towards the Qing Empire and China in general (Kattaev 1994: 54-57). In the description of the activities of the descendants of Makhdumi A'zam, the author uses the term 'Dahbid Xojas' (dahbediy hojalar). History, thus, acts as a resource for the preservation of identity in the context of nation building and globalisation.

According to Kattaev, Dahbid's Xojas are not presented as victims of the Soviet regime; on the contrary, they are carriers of knowledge on Islam and Sufism even in the Soviet period (Kattaev 1994: 77). Researchers have demonstrated that many imams of mosques in Samarqand were the descendants of imams, ulama, of the pre-Soviet era, including the descendants of Makhdumi A'zam, and they 'had maintained a level of Islamic learning through the Soviet period' (Rasanayagam 2014: 11). In the analysis of Kattaev's book, in comparison to the hagiographies and publications of the pre-Soviet period, it is revealed that in his use of different sources, there was an influence of local pre-Soviet traditional methods on the account of the history of the family and the descendants of Mahdumi A'zam. Nevertheless, secularised society, Soviet education and academic science also strongly influenced the author's views.

Twenty-five years have passed since the publication of the book by Kattaev, which was well received by the descendants of the sacred families in Uzbekistan and Kazakhstan. After the collapse of the USSR, some families of Kazakh Xojas held memorial events, to which some descendants of Makhdumi A'zam from Uzbekistan were invited as relatives and carriers of knowledge about the history of these sacred lineages and possibly as experts on genealogies (interview with Kattaev, 2019). The purpose of these events was to restore the historical knowledge on the history of sacred lineages and their contribution to the cultural history of the region. These processes are more related to symbolic meanings. After the announcement by the president of Uzbekistan, Shavkat Mirziyoyev, of the policy of close good-neighbourly relations with the countries of Central Asia (since 2016), communications between the populations of these countries have improved.

According to my observations, in the contemporary period, there are differences in the perception of the past among sacred families depending on the region. For example, while in the capital of Uzbekistan, Tashkent, with 
its multinational population, the young generations have a weak knowledge about the history of sacred families (Malikov 2018b: 141), in the Samarqand region, especially in the last decade, the opposite is true. After 2010, I met more than once young people - the representatives of sacred lineages - who were interested in their history and even published articles and books on the history of certain saints and shrines.

\section{Genealogies and Kinship System of the Descendants of Makhdumi A’zam}

Researchers ask the question: are all members of the descent group equally related to the ancestor and to each other? According to David Schneider (1984), family configurations are seen as historically and locally variable symbolic constructs. Certain groups of sacred lineages living in a vast area of Central Asia and western China are actually the descendants of Makhdumi A'zam, but there are local lineages whose origins are questioned by his descendants in Samarqand. In addition, there is a discourse about the authenticity of the genealogies of some groups claiming the status of descendants of the Prophet Muhammad.

Local perceptions of the system of kinship of sacred lineages have an impact on the formation of people's identities. Ideas about kinship can be manipulated according to various tactical priorities and interests, while recognising or denying specific relationships and relatives (Parkin 2013: 2). In certain social and cultural situations, certain terms of kinship may be used as unifying symbols of different ethnic and social groups. In other cases, people use certain terms of kinship to emphasise their distinction.

Sacred lineages speaking Tajik and Uzbek use the term avlod to refer to their line of origin. Sacred lineages are more specific than non-religious avlods in tracing genealogical lines, as it is the genealogical line that emphasises their high status and association with Islamic saints and even the Prophet Muhammad.

Before 1917, genealogy was the main legal and symbolic record of sacred lineages, and it granted these groups certain rights (Malikov 2018b: 131). Many written genealogies were destroyed during the Soviet rule. The descendants of Makhdumi A'zam in Dahbid and Samarqand preserved medieval handwritten versions of their genealogies. The preservation of certain knowledge on the history of sacred lineages and their genealogies was facilitated by family traditions. Prior to the establishment of the Soviet power, there were often discussions among sacred lineages and power structures about the authenticity of written genealogies, so high legal status and rights were given to the families who had them (interview with Khoja, Samarqand, 2019).

For Kattaev, in the construction of his history, it was important to describe his kinship ties with other sacred lineages. His mother was the descendant of 
another Sufi leader, Xoja Ahrar Vali. Komilkhon's grandmother belonged to the Mirakoni ${ }^{8}$ Sayyids, who had been judges of the Samarqand region since the seventeenth century. Makhdumi A'zam's descendants have contracted marriages with the families of Sayyid Ata's descendants in Samarqand (interview with Kattaev, Samarqand, 2019). This custom differs in Kazakhstan, where the descendants of Makhdumi A'zam, Qilishti ${ }^{9}$ Xojas, distinguish their group from the Xojas of the group of Sayyid Ata (Privratsky 2004: 171).

Kattaev states that by silsilai sharif (the genealogy of Sayyids) and through his father and mother he reaches through 30 generations to the Prophet Muhammad himself. By silsilai zahab (Sufi genealogy) he reaches the Prophet through 31 pirs (Sufi master or spiritual guide) (interview with Kattaev, Samarqand, 2019).

The descendants of Makhdumi A'zam in Samarqand have their own kinship terminology. For example, Sayyids call their sister otob, while Uzbeks use opa (interview, rural resident of Samarqand province, 2005). Some kinship terms even differ from those used by the Uzbek and Tajik populations of the Samarqand region.

The terminology of the kinship of the sacred families of Samarqand differs from the Uzbek-speaking and Kazakh-speaking Xojas of Turkistan (Malikov 2017). Uzbek-speaking Xojas and Sayyids in the Samarqand province of Uzbekistan consider the descendants of Tajik-speaking religious elite groups in the region and outside to be their relatives.

When speaking of the endogamous marriages of Xojas, some respondents referred to the words of elders: 'qarindoshlaringga qiz berib, qiz olib turinglar, uzoqlashib ketmaysizlar' (contract the marriage of your daughters with relatives and marry your relatives - thanks to this you will not distance yourself) (interviews, Xojas of Zhumabazar, 2005). Currently, some families among the descendants of the sacred lineages retain group endogamy. According to respondents, internal marriages allow them to preserve their values and high standards of morality. The situation differs from the pre-Soviet era, when endogamy was due to the high economic and legal status of the sacred lineages. In determining the related groups with which marriages are made, the descendants of Makhdumi A'zam rely on the traditions of pre-Soviet times. Of course, there are cases where relatives who live in other regions of Central Asia were identified after the fall of the USSR. During the Soviet period, they were forced to hide their origin because of the fear of persecution by the authorities, and now there is no such threat.

There were also changes in marriage traditions in the Soviet period, meaning that more Xoja families formed marriage alliances with the non-Xoja elite (Abashin 2005). However, this observation does not find confirmation among the descendants of Makhdumi A'zam in Samarqand, who mostly follow group endogamy. My data indicates that the families with whom members of the Makhdumi A'zam descendants have established marriage bonds are very important for defining their social status. 
Thus, under the conditions of a secular state, when civil laws function instead of the sharia, and sacred families have lost their monopoly in jurisprudence and the right to a waqf property, Xojas have justified endogamous marriages via social and family reasons.

\section{Shrines as Symbols of Group Identity}

Until the 1920s, shrines were important for the identity and the status of sacred lineages. Shrines with graves of charismatic descendants of the Prophet Muhammad and Sufi leaders had a sacral status in the eyes of the population. The descendants of saints who were the owners of shrines received high incomes from waqfs, legalised by power and the donations of the population. In the Soviet period, beginning from the late 1920s, due to the policy of promoting atheism, shrines were deprived of this status, and were turned into museums at best and destroyed at worst. Holy families were denied legal rights to the shrines and the property they owned. Until the 1930s, the mazar $^{10}$ in Dahbid served as a burial place for the numerous family members of Makhdumi A'zam. Nearby was a Sufi center that was led by the descendants of Makhdumi A'zam, who always conveyed considerable spiritual and political authority (interview, resident of Dahbid, 2007).

At present, shrines in Samarqand can be divided into several categories. After Uzbekistan's independence, some came completely under the control of the government (e.g. Shah-i-Zinda, Xoja Daniyar), while others were rebuilt in the 1990s by private initiators (e.g. the shrine of the Sufi saint Nur al-Din Basir) (Malikov 2018a: 139).

Makhdumi A'zam's shrine (mazar) in Dahbid was not returned to its descendants but remained in the implementation of the state as a museum. Thus, the policy of the Soviet government on the museumification of shrines has been preserved up to the present. Older Dahbid residents talk with nostalgia about the high status of the village and its shrine in the past.

The shrine in Dahbid is an important symbol of the identity of Makhdumi A'zam's descendants. On the one hand, their ancestors are buried here, whom it is necessary to revere, to show respect for their memory. Group solidarity is emphasised during a collective pilgrimage to the shrine by the descendants of the saint from different parts of Central Asia. These descendants now speak different languages - Tajik, Uzbek, Kazakh - but they believe that they are bound by common roots of origin. On the other hand, the importance of the shrine in the eyes of the population is reinforced by the fact that not only the descendants of the saint are buried in the cemetery, but also famous political figures of the Middle Ages, who were buried next to Makhdumi A'zam and his descendants. 


\section{Conclusion}

Over the past 150 years, the sacred families of Samarqand have been and still are going through complex transformation processes associated with many factors. Starting from the conquest of Samarqand by the Russian Empire, sacred families began to lose their former political and economic status and resources. The abolition of sharia, the policy of atheism, secularism, class struggle, the changing of the alphabet, the physical destruction of the members of the former religious elite and the formation of national stories in the Soviet era caused tragic consequences for the members of sacred families. The values and foundations of the Muslim society in Samarqand have changed. The analysis of the history and narratives of a sacred family of the descendants of Makhdumi A'zam shows that despite the preservation of the historical family library, a secularised society and Soviet-era education influenced the views and the identity of sacred families.

After Uzbekistan's independence, the descendants of sacred families have made no demands to the authorities for the establishment of previous privileges and property. Intellectually, sacred families showed activity in two areas: revival of historical knowledge on the region within the framework of the national ideology of Uzbekistan and the study of the history of sacred families and their genealogies within the framework of the history of Central Asia. In the search for relatives, the descendants of Makhdumi A'zam, the Xojas of the Turkistan region of Kazakhstan and the southern regions of Uzbekistan, showed notable activity. My material demonstrates that individual and collective identities are closely interrelated. On the one hand, the collective identity in the form of a family identity, a descent group, has a significant influence on the formation of the individual identity. On the other hand, the activism of intellectuals publishing stories and genealogies of sacred families has an impact on collective identities and the changing of people's perceptions of their social group. A third factor influencing the identity of the descendants of sacred families are the representations of the population around them, giving them respect as the descendants of the Prophet or Sufi saints and carriers of special charisma.

\section{Acknowledgements}

This work was supported by the European Regional Development Fund Project 'Sinophone Borderlands: Interaction at the Edges' (CZ.02.1.01/0.0/0.0/16_019/ 0000791). My special thanks are extended to the editor and anonymous reviewers for their comments and remarks on an earlier version of this article. I am also grateful to my daughter Farida Malikova for her help with language editing of my article. 
Azim Malikov is Senior Researcher in the Department of Asian Studies, Faculty of Arts, Palacky University, Olomouc. He was Senior Research Fellow in the Department of Anthropology and Ethnology at the Institute of the History of Academy of Sciences of the Republic of Uzbekistan. From 2010 to 2013, he was Postdoctoral Fellow at the Max Planck Institute for Social Anthropology. His research interests focus on ethnicity and identity, social and cultural transformations of the society in Central Asia, the history of Samarqand, Islamic shrines and sacred lineages in Central Asia. Email: azimmal2018@gmail.com. ORCID: 0000-0002-0173-2014.

\section{Notes}

1. The Sayyids consist of people who claim to have a direct patrilineal descent from the Prophet Muhammad through his daughter Fatima.

2. The terms 'Xoja', 'Khwaja' and 'Khodja' (which means 'master' in Persian) have been taken to imply, variously, descent from 'Arabs', descent from the Prophet or Ali, descent from the first caliphs or descent from Islamising saints. It is worth mentioning that the term 'Xoja' has various meanings, for example, a teacher, a mullah, a title of honour and so on.

3. Ishan, which means 'they' in Persian, is a title or nickname in Central Asia that was given to leaders (of diverse levels) of Sufi brotherhoods and their descendants.

4. The Bukhara Emirate (1756-1920) was one of the three Uzbek khanates ruled by the Manghyt dynasty (1756-1920).

5. Waqf is an Islamic legal institution, the charitable endowment (McChesney 1991).

6. In the nineteenth century, in Samarqand, the Naqshbandia Sufi brotherhood had the greatest influence.

7. Qarakhanid or Ilak-khanids was a Turkic dynasty that ruled in eastern Turkestan and Central Asia (840-1212).

8. Ancestors of Mirakoni Sayyids came from Iran to Samarqand in the seventeeth century.

9. Qilishti means 'with sword' in Kazakh. In Kazakh society, based on its social structure, special names were invented for each sacred lineage.

10. A mazar is a shrine or enshrined tomb of a Sufi saint, distinguished religious leader or descendant of the Prophet Muhammad.

\section{References}

Abashin, S.N. (2001), 'Potomki svyatykh v sovremennoi Srednei Azii', Etnograficheskoye obozreniye, no. 4: 62-83.

Abashin, S.N. (2003), 'Burkhaniddin-Kylych: Uchenyi, pravitel', chudotvorets? O genezise kul'ta sviatykh v Srednei Azii', in Podvizhniki islama: Kul't sviatykh $i$ sufizm v Srednei Azii i na Kavkaze, (Moscow: Vostochnaia literatura), 215-236. 
Abashin, S.N. (2005), 'Gellner, the "Saints" and Central Asia: Between Islam and Nationalism', InnerAsia 7, no. 1:65-86, https://doi.org/10.1163/146481705793647017. Abramson, D. (2001), 'Identity Counts: The Soviet Legacy and the Census in Uzbekistan', in Census and Identity: The Politics of Race, Ethnicity, and Language in National Censuses, (ed.) D. Kertzer and D. Arel, (Cambridge: Cambridge University Press), 176-201.

Adams, L. (2010), The Spectacular State: Culture and National Identity in Uzbekistan (Durham, NC: Duke University Press).

Adams, L. (2013), 'Ethnicity and the Politics of Heritage in Uzbekistan', Central Asian Survey 32, no. 2: 115-133.

Akhmedov, B.A. (1985), Istoriko-geograficheskia literatura Sredney Azii XVI-XVIII vv. (pismennie pamiatniki) (Tashkent: Fan).

Barth, F. (1994), 'Enduring and Emerging Issues in the Analysis of Ethnicity', in The Anthropology of Ethnicity: Beyond 'Ethnic Groups and Boundaries', (ed.) H. Vermeulen and C. Govers (Amsterdam: Het Spinhuis), 11-32.

Bartold, V. (1963), Sochinenia. Volume 2. Part 1. (Moscow: Nauka).

Bennett, J. (2015), 'Narrating Family Histories: Negotiating Identity and Belonging through Tropes of Nostalgia and Authenticity', Current Sociology 66, no. 3: 449-465, https://doi.org/10.1177/0011392115578984.

Bernheimer, T. (2005), 'The Rise of Sayyids and Sadat: The Al Zubara and Other Alids in Ninth-to Eleventh-Century Nishapur', Studia Islamica 100, no. 1: 43-69.

Burke, P. (2003), 'Relationships among Multiple Identities', in Advances in Identity Theory and Research, (ed.) P.J. Burke, T.J. Owens, R. Serpe and P. Thoits (New York: Kluwer Academic/Plenum Publishers), 195-216.

Friedman, J. (1992), 'The Past in the Future: History and the Politics of Identity', American Anthropologist, n.s., 94, no. 4: 837-859.

Giddens, A. (1991), Modernity and Self-Identity: Self and Society in the Late Modern Age (Polity Press).

Holy, L. (1996), Anthropological Perspectives on Kinship (London: Pluto Press).

Ibadullaeva, Z.O. (2001), 'Qazaq khalkynyn kuramyndagy kozhalar (tarikhi-etnografik zertteu)’ (PhD diss., Almaty, Sh.Ualikhanov atindaghy Tarikh jane etnologiya instituti).

Jenkins, R. (2008), Social Identity, 3rd ed. (London: Routledge).

Kattaev, K. (1994), Makhdumi A'zam va Dahbed (Samarqand: Su'gdiyon).

Kattaev, K. (2015), Makhdumi A'zam Dahbediy va uning mashhur avlodlaridan meros qolgan qadimiy nodir kitoblar katalogi: Shahsiy kutubkhona manbalari tahlili birinchi kitob. [Catalogue of antique and unique books left after Makhdumi Agzam Dahbidi and his famous descendants]. Tashkent: Tafakkur bostoni.

Khalid, A. (2014), Islam after Communism: Religion and Politics in Central Asia (Berkeley: University of California Press).

Khalid, A. (2015), Making Uzbekistan: Nation, Empire, and Revolution in the Early USSR. (Ithaca, NY: Cornell University Press).

Layder, D. (2004), Social and Personal Identity: Understanding Yourself (London, Thousand oaks. New Delhi: Sage).

Louw, M.E. (2007), Everyday Islam in Post-Soviet Central Asia (London: Routledge).

Malikov, A. (2017), 'Kinship Systems of Xoja Groups in Southern Kazakhstan', Anthropology of the Middle East 12, no. 2: 78-91. 
Malikov, A. (2018a), 'The Politics of Memory in Samarkand in Post-Soviet Period', International Journal of Modern Anthropology 2, no. 11: 127-145, http://dx.doi.org/ 10.4314/ijma.v2i11.6.

Malikov, A. (2018b), 'Sacred Lineages in Central Asia: Translocality and Identity', in Mobilities, Boundaries, and Travelling Ideas: Rethinking Translocality Beyond Central Asia and the Caucasus, (ed.) M. Stephan-Emmrich and P. Schröder (Cambridge: Open Book Publishers), 121-150.

Malikov, A. (2019), 'Russian Policy toward Islamic "Sacred Lineages" of Samarqand Province of Turkestan Governor-Generalship in 1868-1917’, Acta Slavica Iaponica, no. 40.

McChesney, R.D. (1991), Waqf in Central Asia: Four Hundred Years in the History of a Muslim Shrine, 1480-1889 (Princeton, NJ: Princeton University Press).

Morimoto, K. (2004), 'Toward the Formation of Sayyido-Sharifology: Questioning Accepted Fact', Journal of Sophia Asian Studies 22: 87-103.

Papas, A. (2018), 'Khojas of Kashgar', in Oxford Research Encyclopaedia of Asian History (New York: Oxford University Press), https://oxfordre.com/asianhistory/ view/10.1093/acrefore/9780190277727.001.0001/acrefore-9780190277727-e-12 (accessed 12 January 2019).

Parkin, R. (2013), 'Relatedness as transcendence: the renewed debate over the significance of kinship', Journal of the Anthropological Society of Oxford 5 (1): 1-26.

Privratsky, B.G. (2004), “Turkistan Belongs to the Qojas": Local Knowledge of a Muslim Tradition in Devout Societies vs. Impious States? Transmitting Islamic Learning in Russia, Central Asia and China, through the 20th Century', in Devout Societies vs. Impious States? Transmitting Islamic Learning in Russia, Central Asia and China, through the Twentieth Century, (ed.) S.A. Dudoignon, (Berlin: Klaus Schwarz Verlag), 161-212.

Rasanayagam, J. (2014), 'The Politics of Culture and the Space for Islam: Soviet and Post-Soviet Imaginaries in Uzbekistan', Central Asian Survey 33, no. 1: 1-14.

Roy, O. (2000), The New Central Asia: The Creation of Nations (New York: New York University Press).

Schlee, G. (1994), Identities on the Move: Clanship and Pastoralism in Northern Kenya (Nairobi: Gideon S. Were Press).

Schneider D. M. (1984), A Critique of the Study of Kinship. (University of Michigan Press).

Schoeberlein-Engel, J. (1994), 'Identity in Central Asia: Construction and Contention in the Conceptions of "Ozbek", "Tajik", "Muslim", "Samarqandi" and other groups' (PhD diss., Harvard University).

Shamsuddinov, R. and Kholmirzaev, E. (2015), Kollektivlashtirish va 'katta terror' davrida qatag'on qilingan vatandoshlarimizning xotira kitobi: Samarqand viloyati (1929-1939 yillar) - ikkinchi kitob (Tashkent: Yangi asr avlodi).

Sukhareva, O.A. (1960), Islam v Uzbekistane (Tashkent: Izdatelstvo Akademii nauk Uzbekskoi SSr.).

Woods, M. (1998), 'Rethinking Elites: Networks, Space, and Local Politics', Environment and Planning A 30: 2101-2119.

Yaoyi, K. (2010), “'Sviatie semeistva” Margelana v Kokandskom khanstve v XIX v., Pax Islamica 1, no. 4: 121-139. 